\title{
Addition of brewing spent grains from malt and rice adjunct to the formulation of high fiber biscuit: effects of particle size of brewing spent grains on the product quality
}

\author{
Tran, T.T.T., Ton, N.M.N., Le, N.D.D. and *Le, V.V.M. \\ Department of Food Technology, Ho Chi Minh City University of Technology, Vietnam National \\ University - Ho Chi Minh City (VNU-HCM)
}

\author{
Article history: \\ Received: 17 March 2020 \\ Received in revised form: 19 \\ April 2020 \\ Accepted: 23 April 2020 \\ Available Online: 4 May \\ 2020
}

Keywords:

Biscuit,

Brewing spent grains,

Dietary fiber,

Particle size

\section{DOI:}

https://doi.org/10.26656/fr.2017.4(5).110

\begin{abstract}
Brewing spent grains are considered as a dietary fiber source in the making of many food products. In this study, brewing spent grains from malt and rice adjunct were dried, sieved and mixed with wheat flour in the making of high fiber biscuit. The impacts of particle size of brewing spent grains to the proximate composition, the physical properties and the sensory score of the obtained biscuit were investigated. When the pore size of the brewing spent grains sieve was reduced from 0.60 to $0.21 \mathrm{~mm}$, the protein content of the biscuit sample was enhanced, the total fiber content was decreased while the lipid, ash and phenolic content was similar to that of the control sample. Reduction in particle size of brewing spent grains also led to increased thickness and sensory score of the product; however, the biscuit hardness remained constant. With the recovery yield of $85.6 \%$, the brewing spent grains passed through $0.40 \mathrm{~mm}$ sieve were an appropriate dietary fiber source for partial replacement of wheat flour in the high fiber biscuit production.
\end{abstract}

\section{Introduction}

Biscuit is a well-known industrial food product in the world. This bakery product is rich in sugar, starch and lipid but poor in dietary fiber (Mishra and Chandra, 2012). For human nutrition, high fiber food has become popular due to many health benefits including improvement in laxation and weight management, prevention of obesity and colon inflammation, reduction of risks for cardiovascular disease (Slavin, 2013). Use of dietary fiber materials and sweeteners in biscuit making has attracted great attention. Various dietary fiber sources have been applied to the formulation of high fiber biscuit such as cereal bran (Nandeesh et al., 2011; Khalil et al., 2015), fruit processing residue (Ajila et al., 2008; Obafaye and Omoba, 2018) and brewing spent grains (BSG) (Kirssel and Prentice, 1979; Öztürk et al., 2002; Petrović et al., 2017).

BSG is a by-product of the brewing industry. This by -product is rich in dietary fibers including cellulose, hemicellulose and lignin. In addition, BSG also contains protein, ash, vitamins and phenolic compounds with antioxidant capacity (Meneses et al., 2013). It can be noted that in the previous studies, BSG is originated from the mashing in which $100 \%$ barley malt is used. In tropical countries, barley cannot be cultivated and barley malt must be imported; adjunct is widely used in brewing to partially replace barley malt (Le Van et al., 2001). It can be inferred that the proximate composition of BSG from barley malt mashing and that from barley malt and adjunct mashing would be different. However, proximate composition and use of BSG from barley malt and adjunct mashing in biscuit making have not been reported in the literature.

Addition of dietary fiber materials to biscuit formulation improves nutritional value but reduces some textural properties as well as the sensory quality of the product (Quiles et al., 2018). For BSG from barley malt mashing, the effects of their particle size on the main composition, spread factor and overall sensory score of biscuit are investigated (Öztürk et al., 2002); however, the antioxidant capacity, as well as the hardness of the BSG added biscuit is unknown. In this study, for the first time, BSG from barley malt and rice adjunct was used to partially replace wheat flour for high fiber biscuit making. The effects of particle size of BSG on the product quality including proximate composition, physical properties and sensory score were investigated. The objective of the study was to select the appropriate size of brewing spent grains for the production of biscuit with high fiber content. 


\section{Materials and methods}

\subsection{Materials}

Brewing spent grains were originated from the $75 \%$ barley malt and $25 \%$ rice mashing and provided by Saigon Brewery (Ho Chi Minh city, Vietnam). The fresh BSG were dried at $70^{\circ} \mathrm{C}$ for $5 \mathrm{hrs}$ until the moisture content was less than $10 \%$. The dried BSG were ground in a roller mill and equally divided into three portions; each portion was sifted through a sieve. The apertures of the three sieves were $0.60,0.40$ and $0.21 \mathrm{~mm}$, respectively. The obtained $\mathrm{BSG}$ samples through the three sieves were preserved in polyethylene bags at $4^{\circ} \mathrm{C}$ and used for experimentation. Wheat flour was supplied from Dai phong company (Ho Chi Minh city, Vietnam).

Other ingredients used for biscuit making included fresh chicken eggs, isomalt, acesulfame potassium, butter, sodium chloride, vanilla flavor, baking powder containing ammonium carbonate, sodium bicarbonate and wheat flour. These ingredients were purchased from a local supermarket in Ho Chi Minh City, Vietnam.

All chemicals used in the study were supplied by Sigma-Aldrich (USA) and they were of analytical grade.

\subsection{Experimentation}

For high fiber biscuit making, the weight ratio of wheat flour and BSG was fixed at $80 \%$ and $20 \%$ (Lam et al., 2019); three biscuit samples $\mathrm{A}, \mathrm{B}$ and $\mathrm{C}$ were prepared from BSG which were sifted through the sieve with apertures of $0.60,0.40$ and $0.21 \mathrm{~mm}$, respectively. The total weight of wheat flour and BSG was $1 \mathrm{~kg}$ for each biscuit sample. Control biscuit sample D was prepared from wheat flour without BSG addition.

The ratio of all ingredients of the formulation of high fiber biscuit as well as the baking procedure was described in the previous study (Lam et al., 2019). At the end of the baking, the product was naturally cooled down to the ambient temperature, packaged in polyethylene bag and immediately used for analysis.

\subsection{Chemical analysis}

Moisture content was determined by drying at $105^{\circ} \mathrm{C}$ to constant weight (Bradley, 2010). Lipid content was evaluated by Soxhlet extraction with diethyl ether (Min and Ellefson, 2010). Total protein content was estimated by Kjeldahl - Nessler method (AOAC, 2016). Ash content was quantified by heating at $550^{\circ} \mathrm{C}$ to constant weight (AOAC, 2000). Total carbohydrate content was determined by the phenol sulfuric acid method (BeMiller, 2010). Dietary fibers including total, soluble and insoluble fiber were measured by AOAC 985.29 method (McCleary et al., 2013).

\subsection{Physical analysis}

The particle size distribution of wheat flour and BSG was measured using a laser diffraction particle size distribution analyzer (Model LA 920; Horiba, Japan); the mean particle size $\left(d_{4,3}\right)$ and specific surface area were determined using LA-920 software (Horiba). Water holding capacity and oil holding capacity were evaluated by the procedure previously described elsewhere (Nwabueze, 2006). Diameter, thickness and spread factor of biscuit were determined by the method previously described elsewhere (Mishra and Chandra, 2012). The hardness of cookies was measured using texture profile analyzer (Model 5543, Instron, USA) (Noor Aziah et al., 2012). Instrumental color was evaluated using a colorimeter (Model CR-300, Minolta, Japan); color data were recorded as CIE L*, a*, b* coordinates, indicating lightness $(0-100)$, green-red, and blue-yellow, respectively. The total color difference between the BSG added biscuit and the control was calculated by the formula previously described elsewhere (Pathare et al., 2013).

\subsection{Sensory analysis}

Sensory score of the cookies samples was evaluated using an acceptance test and 9-point hedonic scale. The panelists gave score 1-9 to the samples, ranging from "extremely dislike" to "extremely like" (Meilgaard et al., 2006). Sixty panelists were selected for the sensory evaluation.

\subsection{Statistical analysis}

All experiments were performed in triplicate and the obtained results were presented as means \pm standard deviation $(n=3)$. Mean values were considered significantly different when the probability was less than 0.05 using multiple range test. One-way analysis of variance was conducted by using software Statgraphics Centurion XV (Manugistics Inc., Rockville, USA).

\section{Results and discussion}

\subsection{Proximate composition and physical properties of} brewing spent grains and wheat flour

Table 1 presents proximate composition and physical properties of BSG from barley malt and rice mashing and wheat flour used in the study. The particle size of BSG was much larger than that of wheat flour. When the sieve aperture size decreased from 0.60 to $0.21 \mathrm{~mm}$, the mean particle size of BSG reduced by $31 \%$ while their specific surface area increased by $27 \%$; in addition, the recovery yield of BSG decreased by $30 \%$. High recovery yield of BSG may reduce the cost of the final product.

It can be noted that the protein and lipid content of 
Table 1. Recovery yield, proximate composition and physical properties of brewing spent grains and wheat flour

\begin{tabular}{|c|c|c|c|c|}
\hline & \multirow{2}{*}{ Wheat flour } & \multicolumn{3}{|c|}{ Brewing spent grains passed through sieve with apertures of } \\
\hline & & $0.60 \mathrm{~mm}$ & $0.40 \mathrm{~mm}$ & $0.21 \mathrm{~mm}$ \\
\hline Recovery yield (\%) & Non-determined & $92.8 \pm 0.7^{\mathrm{a}}$ & $85.6 \pm 0.6^{\mathrm{b}}$ & $65.4 \pm 0.2^{\mathrm{c}}$ \\
\hline Mean particle size $(\mu \mathrm{m})$ & $75.4^{\mathrm{d}}$ & $149.9^{\mathrm{a}}$ & $128.4^{\mathrm{b}}$ & $103.9^{\mathrm{c}}$ \\
\hline Specific surface area $\left(\mathrm{cm}^{2} / \mathrm{cm}^{3}\right)$ & $1587^{\mathrm{a}}$ & $1123^{\mathrm{d}}$ & $1230^{\mathrm{c}}$ & $1429^{b}$ \\
\hline Moisture (\%) & $12.1 \pm 0.1^{\mathrm{a}}$ & $7.7 \pm 0.1^{b}$ & $7.6 \pm 0.1^{\mathrm{bc}}$ & $7.4 \pm 0.1^{\mathrm{c}}$ \\
\hline Protein (\% dry weight) & $9.9 \pm 0.1^{\mathrm{d}}$ & $22.7 \pm 0.2^{\mathrm{c}}$ & $24.8 \pm 0.3^{\mathrm{b}}$ & $28.2 \pm 0.3^{\mathrm{a}}$ \\
\hline Lipid (\% dry weight) & $2.5 \pm 0.1^{\mathrm{c}}$ & $12.5 \pm 0.2^{b}$ & $13.0 \pm 0.2^{\mathrm{a}}$ & $13.5 \pm 0.2^{\mathrm{a}}$ \\
\hline Ash (\% dry weight) & $0.7 \pm 0.0^{\mathrm{c}}$ & $4.0 \pm 0.1^{\mathrm{a}}$ & $3.9 \pm 0.1^{\mathrm{a}}$ & $3.3 \pm 0.1^{\mathrm{b}}$ \\
\hline Starch (\% dry weight) & $85.5 \pm 0.5^{\mathrm{a}}$ & $4.2 \pm 0.1^{\mathrm{b}}$ & $4.1 \pm 0.1^{b}$ & $4.0 \pm 0.1^{\mathrm{b}}$ \\
\hline Soluble fiber ( $\%$ dry weight) & $1.5 \pm 0.1^{\mathrm{c}}$ & $8 \pm 0.3^{\mathrm{a}}$ & $7.9 \pm 0.4^{\mathrm{a}}$ & $7.5 \pm 0.2^{b}$ \\
\hline Insoluble fiber ( $\%$ dry weight $)$ & $2.0 \pm 0.0^{\mathrm{d}}$ & $47.2 \pm 0.7^{\mathrm{a}}$ & $45.8 \pm 0.8^{\mathrm{b}}$ & $43.1 \pm 0.7^{\mathrm{c}}$ \\
\hline Total fiber ( $\%$ dry weight $)$ & $3.5 \pm 0.1^{\mathrm{d}}$ & $55.2 \pm 1.0^{\mathrm{a}}$ & $53.6 \pm 0.9^{\mathrm{b}}$ & $50.5 \pm 0.9^{c}$ \\
\hline Total carbohydrate (\% dry weight) & $87.0 \pm 0.2^{\mathrm{a}}$ & $60.8 \pm 0.1^{\mathrm{b}}$ & $58.4 \pm 0.0^{\mathrm{c}}$ & $55.1 \pm 0.5^{\mathrm{d}}$ \\
\hline Total phenolics (mg GAE/kg dry weight) & $1514 \pm 6^{\mathrm{d}}$ & $1842 \pm 3^{\mathrm{a}}$ & $1671 \pm 1^{\mathrm{b}}$ & $1611 \pm 2^{\mathrm{c}}$ \\
\hline $\begin{array}{l}\text { Antioxidant capacity by DPPH assay } \\
\text { ( } \mu \mathrm{MTE} / \mathrm{kg} \text { dry weight) }\end{array}$ & $527 \pm 34^{\mathrm{d}}$ & $6345 \pm 6^{\mathrm{a}}$ & $5864 \pm 4^{b}$ & $5033 \pm 8^{\mathrm{c}}$ \\
\hline $\begin{array}{l}\text { Antioxidant capacity by FRAP assay } \\
\text { ( } \mu \mathrm{MTE} / \mathrm{kg} \text { dry weight) }\end{array}$ & $696 \pm 7^{\mathrm{d}}$ & $8817 \pm 3^{\mathrm{a}}$ & $7894 \pm 5^{b}$ & $7623 \pm 4^{\mathrm{c}}$ \\
\hline $\mathrm{L}^{*}$ & $92.6 \pm 0.2^{b}$ & $67.1 \pm 0.4^{\mathrm{a}}$ & $66.8 \pm 1.2^{\mathrm{a}}$ & $65.5 \pm 0.4^{\mathrm{a}}$ \\
\hline$a^{*}$ & $-6.7 \pm 0.2^{\mathrm{a}}$ & $-0.5 \pm 0.0^{\mathrm{d}}$ & $-0.7 \pm 0.0^{\mathrm{c}}$ & $-0.8 \pm 0.0^{\mathrm{b}}$ \\
\hline$b^{*}$ & $13 \pm 0.3^{b}$ & $20.2 \pm 0.1^{\mathrm{a}}$ & $20.1 \pm 0.1^{\mathrm{a}}$ & $20.1 \pm 0.2^{\mathrm{a}}$ \\
\hline Water holding capacity (g/g) & $1.3 \pm 0.0^{\mathrm{d}}$ & $3.8 \pm 0.0^{\mathrm{a}}$ & $3.7 \pm 0.0^{\mathrm{b}}$ & $3.6 \pm 0.0^{\mathrm{c}}$ \\
\hline Oil holding capacity (g/g) & $0.8 \pm 0.0^{\mathrm{d}}$ & $1.8 \pm 0.0^{\mathrm{c}}$ & $1.9 \pm 0.0^{\mathrm{b}}$ & $2.0 \pm 0.0^{\mathrm{a}}$ \\
\hline
\end{tabular}

Values with different subscripts in the same row are significantly different $(\mathrm{P}<0.05)$

BSG was much higher than that of wheat flour. When the sieve aperture size reduced from 0.60 to $0.21 \mathrm{~mm}$, the protein and lipid content of BSG increased by $24 \%$ and $8 \%$, respectively. That is due to the non-uniform distribution of protein and lipid in barley grain. Grain embryo has a harder structure as well as higher protein and lipid content than its endosperm (Kulp, 2000). Consequently, the milling product of embryo has a smaller size than that of endosperm and the BSG sample with small particle size is richer in protein and lipid than that with large particle size. Previously, fine BSG were reported to have higher protein content than coarse BSG (Öztürk et al., 2002). In addition, BSG contained a higher amount of ash than wheat flour. Nevertheless, the ash content in the three BSG samples was statistically similar. These data reveal that use of BSG in biscuit formulation may improve the content of protein, lipid and ash of the product.

On the contrary, the BSG contained a much lower amount of starch than the wheat flour. It can be explained that starch hydrolysis is nearly completed within the mashing process in brewing (Mosher and Trantham, 2016). The starch content of three BSG samples was similar. The soluble, insoluble and total fiber content of BSG was much greater than that of wheat flour. When the sieve aperture size decreased from 0.60 to $0.21 \mathrm{~mm}$, the total fiber content reduced by $9 \%$.
Most of fibers of barley grain are located in the grain husk (Duffus and Cochrane, 1993). During the milling, the husk generates the particles with a larger size than the endosperm and the embryo due to its high springiness. Consequently, BSG with a larger particle size is rich in dietary fiber content. Reduction in sieve aperture size from 0.60 to $0.21 \mathrm{~mm}$ also decreased the total carbohydrate content of BSG by $9 \%$ mainly due to a decrease in dietary fiber content.

The total phenolic content and antioxidant capacity of BSG were much greater than those of wheat flour. The lower the sieve aperture size used in BSG sieving, the lower the total phenolic content and antioxidant capacity of the obtained BSG sample. That is due to the high content of phenolic compounds in the grain husk (da Rosa Almeida et al., 2017) and BSG with low particle size contains less milling product of grain husk.

For instrumental color, the BSG had darker color than the wheat flour. It is probably due to Maillard reactions which happen during the mashing process in brewing as well as during the drying of BSG for their preservation. The products of browning reactions enhance the darkness of BSG. In addition, green (negative $\mathrm{a}^{*}$ value) and yellow (positive $\mathrm{b}^{*}$ value) colors were observed for all BSG and wheat flour samples. When the sieve aperture size decreased from 0.60 to 
$0.21 \mathrm{~mm}$, both $\mathrm{a}^{*}$ and $\mathrm{b}^{*}$ values varied within narrow ranges.

The water and oil holding capacities of BSG were greater than those of wheat flour. Reduction in sieve aperture size slightly decreased the water holding capacity of BSG. It can be explained that the hydroxyl group of cellulose may link with water molecules and that improves water holding capacity of fiber material (Foschia et al., 2013). BSG with small particle size contained less fibers and hydroxyl groups than that with large particle size and that lowered water holding capacity. On the contrary, the decrease in sieve aperture size slightly enhanced oil holding capacity of BSG. Oil holding capacity depends on surface properties as well as hydrophilic properties of fiber components (Foschia et al., 2013). The lower number of hydroxyl groups of BSG with small particle size resulted in higher hydrophobic capacity and that increased oil holding capacity.

\subsection{Effects of particle size of brewing spent grains on proximate composition of biscuit}

Proximate composition of biscuit samples is described in Table 2. Three samples A, B and C with BSG had higher moisture content than sample D (control). It is due to high amount of fibers which may link water molecules (Foschia et al., 2013) and that prevents water evaporation during biscuit baking. A similar increase in moisture content is also reported for mango peel powder added biscuit (Ajila et al., 2008).

Addition of BSG to the blend enhanced protein, lipid and ash content of the product since the amount of these components in BSG was greater than that in wheat flour. When the sieve aperture size decreased from 0.60 to 0.21 $\mathrm{mm}$, the protein content of the product was increased by
$20 \%$. That is due to the higher protein level of BSG with a smaller particle size than that with larger particle size. Nevertheless, the lipid and ash content of three samples A, B and C was statistically similar.

Use of BSG reduced the carbohydrate and starch content of the biscuit since the BSG contained less carbohydrate and starch than the wheat flour. The soluble, insoluble and total fiber contents of the product with BSG were 1.7-1.9, 5.2-5.6 and 3.5-3.7 times, respectively higher than those of the control sample. When the sieve aperture size decreased from 0.60 to 0.21 $\mathrm{mm}$, the insoluble and total fiber content slightly reduced while the soluble fiber content was statistically remained unchanged. It can be noted that the total fiber content of biscuit varied from 5.9 to $6.3 \%$ at the wheat flour and BSG ratio of $80 \%$ and $20 \%$, respectively. A food can be considered as fiber food when the total fiber content is at least $6 \mathrm{~g} / 100 \mathrm{~g}$ (Codex Alimentarius, 1997).

Table 2 also reveals that the addition of BSG to the blend significantly improved the phenolic content as well as the antioxidant capacity of the biscuit. That can be explained that various phenolic compounds are identified in BSG including ferulic acid, p-coumaric acid, flavonoids and they contribute to the antioxidant capacity of the final product (Meneses et al., 2013). When the sieve aperture size decreased from 0.60 to 0.21 $\mathrm{mm}$, the phenolic content and antioxidant capacity of the BSG added biscuit remained constant although the phenolic content in the three BSG samples was slightly different (Table 1). It is probably due to moderate ratio of BSG in the biscuit formulation and that does not generate a clear difference in antioxidant content in the final product.

Table 2. Proximate composition of biscuit samples

\begin{tabular}{|c|c|c|c|c|}
\hline & Sample A & Sample B & Sample C & Sample D \\
\hline Moisture (\%) & $5.4 \pm 0.1^{\mathrm{a}}$ & $5.3 \pm 0.1^{\mathrm{b}}$ & $5.0 \pm 0.1^{\mathrm{c}}$ & $3.5 \pm 0.0^{\mathrm{d}}$ \\
\hline Protein (\% dry weight) & $9.7 \pm 0.2^{\mathrm{c}}$ & $10.3 \pm 0.2^{\mathrm{b}}$ & $11.6 \pm 0.3^{\mathrm{a}}$ & $5.0 \pm 0.1^{\mathrm{d}}$ \\
\hline Lipid (\% dry weight) & $27.0 \pm 0.2^{\mathrm{a}}$ & $27.1 \pm 0.1^{\mathrm{a}}$ & $27.3 \pm 0.2^{\mathrm{a}}$ & $24.6 \pm 0.0^{\mathrm{b}}$ \\
\hline Ash (\% dry weight) & $1.2 \pm 0.0^{\mathrm{a}}$ & $1.3 \pm 0.0^{\mathrm{a}}$ & $1.2 \pm 0.0^{\mathrm{a}}$ & $1.0 \pm 0.0^{\mathrm{b}}$ \\
\hline Total carbohydrate ( $\%$ dry weight) & $62.1 \pm 0.6^{\mathrm{b}}$ & $61.0 \pm 0.4^{\mathrm{c}}$ & $59.4 \pm 0.0^{\mathrm{d}}$ & $69.4 \pm 0.1^{\mathrm{a}}$ \\
\hline Starch (\% dry weight) & $45.7 \pm 0.3^{\mathrm{b}}$ & $45.3 \pm 0.1^{\mathrm{b}}$ & $45.2 \pm 0.4^{\mathrm{c}}$ & $50.6 \pm 0.3^{\mathrm{a}}$ \\
\hline Soluble fiber ( $\%$ dry weight) & $1.3 \pm 0.0^{\mathrm{a}}$ & $1.3 \pm 0.1^{\mathrm{a}}$ & $1.2 \pm 0.0^{\mathrm{a}}$ & $0.7 \pm 0.1^{\mathrm{b}}$ \\
\hline Insoluble fiber ( $\%$ dry weight) & $5.0 \pm 0.1^{\mathrm{a}}$ & $4.9 \pm 0.1^{\mathrm{a}}$ & $4.7 \pm 0.1^{b}$ & $0.9 \pm 0.0^{\mathrm{c}}$ \\
\hline Total fiber (\% dry weight) & $6.3 \pm 0.1^{\mathrm{a}}$ & $6.2 \pm 0.1^{\mathrm{a}}$ & $5.9 \pm 0.1^{\mathrm{c}}$ & $1.7 \pm 0.1^{\mathrm{c}}$ \\
\hline Total phenolics (mg GAE/kg dry weight) & $1437 \pm 8^{\mathrm{a}}$ & $1434 \pm 6^{\mathrm{a}}$ & $1434 \pm 7^{\mathrm{a}}$ & $1281 \pm 6^{b}$ \\
\hline Antioxidant capacity by $\mathrm{DPPH}$ assay ( $\mu \mathrm{MTE} / \mathrm{kg}$ dry weight) & $2114 \pm 9^{\mathrm{a}}$ & $2111 \pm 7^{\mathrm{a}}$ & $2108 \pm 5^{\mathrm{a}}$ & $455 \pm 63^{b}$ \\
\hline Antioxidant capacity by FRAP assay ( $\mu \mathrm{MTE} / \mathrm{kg}$ dry weight) & $4077 \pm 4^{\mathrm{a}}$ & $4076 \pm 6^{\mathrm{a}}$ & $4076 \pm 4^{\mathrm{a}}$ & $526 \pm 12^{\mathrm{b}}$ \\
\hline
\end{tabular}

Values with different subscripts in the same row are significantly different $(\mathrm{P}<0.05)$; $\mathrm{A}, \mathrm{B}$ and $\mathrm{C}$ were biscuit samples from $\mathrm{BSG}$ passed through sieve with apertures of $0.60,0.40$ and $0.21 \mathrm{~mm}$, respectively; the wheat flour and brewing spent grains ratio was fixed at $80 \%$ and $20 \%$; D was biscuit sample from wheat flour (control sample). 
3.3 Effects of particle size of brewing spent grains on physical properties of biscuit

Table 3 describes the important physical properties of biscuit samples. Addition of BSG to biscuit formulation slightly decreased diameter and thickness of the obtained product. A similar observation is reported when barley bran is used in biscuit making (Sudha et al., 2007). When the dietary fiber content in the dough increases, the gluten network becomes weaker. As a result, the expansion of the product was reduced (Curti et al., 2013) and that led to a reduced diameter and thickness of the obtained product. When the sieve aperture size decreased from 0.60 to $0.21 \mathrm{~mm}$, both diameter and thickness slightly increased since BSG with small particle size had less fiber content than that with large particle size. The spread factor of all biscuit samples varied within a narrow range of 4.8 to 5.2. A similar result is noted when mango peel powder is added to biscuit formulation (Ajila et al., 2008).

The hardness of the BSG added samples was significantly higher than that of the control sample. High fiber content is responsible for the increased hardness of high fiber biscuit. A similar result is also reported when bamboo shoot powder is added to biscuit formulation (Choudhury et al., 2015). When the sieve aperture size decreased from 0.60 to $0.21 \mathrm{~mm}$, the hardness of the obtained product was statistically similar.

Table 3. Physical properties of biscuit samples

\begin{tabular}{|c|c|c|c|c|}
\hline & Sample A & Sample B & Sample C & Sam \\
\hline Diame & $34.5 \pm 0.7^{\mathrm{c}}$ & $35.3 \pm 0.7^{b}$ & $35.3 \pm 0.5^{\mathrm{b}}$ & $36.6 \pm 0.2^{\mathrm{a}}$ \\
\hline Thickness (mm) & $6.6 \pm 0.4^{\mathrm{c}}$ & $7.1 \pm 0.2^{\mathrm{b}}$ & $7.3 \pm 0.2^{\mathrm{ab}}$ & $7.4 \pm 0.2^{\mathrm{a}}$ \\
\hline Spread factor & $5.2 \pm 0.3^{\mathrm{a}}$ & $5.0 \pm 0.2^{\mathrm{b}}$ & $4.8 \pm 0.2^{\mathrm{b}}$ & $4.9 \pm 0.1^{\mathrm{b}}$ \\
\hline Hardn & $10.8 \pm 0.3^{\mathrm{a}}$ & $10.4 \pm 0.5^{\mathrm{a}}$ & $10.2 \pm 0.4^{\mathrm{a}}$ & $7.5 \pm 0.2^{\mathrm{b}}$ \\
\hline$L^{*}$ & $57.1 \pm 0.3^{\mathrm{b}}$ & & 56.1 & $0.1^{\mathrm{a}}$ \\
\hline$a^{*}$ & $2.2 \pm 0.1^{\mathrm{b}}$ & $2.4 \pm 0.1^{\mathrm{a}}$ & $2.5 \pm 0.1^{\mathrm{a}}$ & $-0.2 \pm 0.1^{\mathrm{c}}$ \\
\hline$b^{*}$ & $23.2 \pm 0.1^{\mathrm{b}}$ & $23.3 \pm 0.2^{\mathrm{b}}$ & $22.4 \pm 0.3^{\mathrm{c}}$ & $33.8 \pm 0.2^{\mathrm{a}}$ \\
\hline$\Delta \mathrm{E}$ & $11.8 \pm 0.2^{b}$ & $12.2 \pm 0.2^{b}$ & $13.0 \pm 0.1^{\mathrm{a}}$ & $0.0 \pm 0.00^{\mathrm{c}}$ \\
\hline
\end{tabular}

Values with different subscripts in the same row are significantly different $(\mathrm{P}<0.05) ; \mathrm{A}, \mathrm{B}$ and $\mathrm{C}$ were biscuit samples from BSG passed through sieve with apertures of $0.60,0,40$ and $0.21 \mathrm{~mm}$, respectively; the wheat flour and brewing spent grains ratio was fixed at $80 \%$ and $20 \%$; D was biscuit sample from wheat flour (control sample).

For instrumental color, all biscuit samples with BSG were darker than the control since the lightness of BSG was lower than that of wheat flour. Enhanced darkness of cookies was previously reported when the percentage of BSG addition gradually increased from 0 to $25 \%$ of the blend weight (Öztürk et al., 2002). It can be explained that BSG is richer in protein than wheat flour; the amino groups of protein and carbonyl groups of carbohydrate in the dough may take part in Maillard reactions resulting in enhanced formation of browning compounds during the biscuit baking. The values of $\Delta \mathrm{E}$ in Table 3 confirm that use of BSG in biscuit making increase the product darkness. However, when the sieve aperture size decreased from 0.60 to $0.21 \mathrm{~mm}$, all values of $\mathrm{L}^{*}$, $\mathrm{a}^{*}$ and $\mathrm{b}^{*}$ varied in narrow ranges. Therefore, change in particle size of BSG did not have a great impact on the product color.

3.4 Effects of particle size of brewing spent grains on the sensory score of biscuit

Sensory scores on the overall acceptability of the biscuit samples are given in Table 4. All biscuit samples were considered acceptable since their overall acceptability score was higher than 5 . The biscuit sample with BSG passed through $0.21 \mathrm{~mm}$ sieve had a similar sensory score to the control sample. Therefore, the use of BSG with small particle size did not affect the sensory properties of the product. Nevertheless, the increase in sieve particle size from 0.21 to $0.60 \mathrm{~mm}$ slightly decreased the sensory score of the biscuit. Reduction in sensory properties of the biscuit is also observed in the previous studies when dietary fiber materials are added to the product formulation (Öztürk et al., 2002). It can be noted that both sample $\mathrm{B}$ and $\mathrm{C}$ had similar sensory score while the recovery yield of BSG passed through $0.4 \mathrm{~mm}$ sieve (for sample B) was much higher than that of BSG passed through $0.21 \mathrm{~mm}$ sieve (for sample $\mathrm{C}$ ). Therefore, BSG passed through $0.4 \mathrm{~mm}$ sieve was appropriate for high fiber biscuit making.

Table 4. Sensory scores on the overall acceptability of biscuit samples

\begin{tabular}{lcccc}
\hline & Sample A & Sample B & Sample C & Sample D \\
\hline Sensory score & $5.1 \pm 1.2^{\mathrm{c}}$ & $5.8 \pm 1.0^{\mathrm{b}}$ & $6.2 \pm 1.2^{\mathrm{ab}}$ & $6.7 \pm 1.3^{\mathrm{a}}$ \\
\hline
\end{tabular}

Values with different subscripts are significantly different $(\mathrm{P}<0.05)$; $\mathrm{A}, \mathrm{B}$ and $\mathrm{C}$ were biscuit samples from $\mathrm{BSG}$ passed through sieve with apertures of $0.60,0,40$ and $0.21 \mathrm{~mm}$, respectively; the wheat flour and brewing spent grains ratio was fixed at $80 \%$ and $20 \%$; D was biscuit sample from wheat flour (control sample).

\section{Conclusion}

BSG with small particle size had higher protein and lipid but lower fiber and phenolics content than that with large particle size. At the wheat flour and BSG ratio of $80 \%$ and $20 \%$, decrease in sieve aperture size for BSB enhanced the protein but reduced fiber and phenolics content of the biscuit. Reduction in BSG particle size also decreased the product thickness and sensory score. BSG passed through $0.4 \mathrm{~mm}$ sieve was appropriate for high fiber biscuit. 


\section{Conflict of interest}

All authors of this manuscript declare no conflict of interest and agree with the content of the manuscript.

\section{Acknowledgement}

This research was funded by the Department of Science and Technology, Ho Chi Minh city, the grant number of 19/2018/HĐ-QKHCN signed on November $28^{\text {th }} 2018$.

\section{References}

Ajila, C. M., Leelavathi, K. and Prasada Rao, U.J.S. (2008). Improvement of dietary fiber content and antioxidant properties in soft dough biscuits with the incorporation of mango peel powder. Journal of Cereal Science, 48(2), 319-326. https:// doi.org/10.1016/j.jcs.2007.10.001

AOAC. (2000). Ash of dried milk. Gaithersburg (MA) US: AOAC International.

AOAC. (2016). Protein (Crude) in Animal Feed, Forage (Plant Tissue), Grain, and Oilseeds. Gaithersburg, Md., USA: AOAC International.

BeMiller, J.N. (2010). Carbohydrate analysis. In Food analysis, p. 147-177. Boston, USA: Springer. https:// doi.org/10.1007/978-1-4419-1478-1_10

Bradley, R.L. (2010). Moisture and total solids analysis. In Food analysis, p. 85-104. Boston, USA: Springer. https://doi.org/10.1007/978-1-4419-1478-1_6

Choudhury, M., Badwaik, L.S., Borah, P.K., Sit, N. and Deka, S.C. (2015). Influence of bamboo shoot powder fortification on physico-chemical, textural and organoleptic characteristics of biscuits. Journal of Food Science and Technology, 52(10), 6742-6748. https://doi.org/10.1007/s13197-015-1709-3

Codex Alimentarius. (1997). Codex Guidelines for use of nutrition and health claims (CAC/GL23-1997, Rev. 1-2004). Retreived from Codex Alimentarius Website: http://www.codexalimentarius.net/web/ more_info.jsp?id_sta $=351$

Curti, E., Carini, E., Bonacini, G., Tribuzio, G. and Vittadini, E. (2013). Effect of the addition of bran fractions on bread properties. Journal of Cereal Science, 57(3), 325-332. https://doi.org/10.1016/ j.jcs.2012.12.003

da Rosa Almeida, A., Geraldo, M.R.F., Ribeiro, L.F., Silva, M.V., Maciel, M.V.D.O.B. and Haminiuk, C.W.I. (2017). Bioactive compounds from brewer's spent grain: phenolic compounds, fatty acids and in vitro antioxidant capacity. Acta Scientiarum. Technology, 39(3), 269-277. https://doi.org/10.4025/ actascitechnol.v39i3.28435

Duffus, C.M. and Cochrane, M.P. (1993). Formation of the barley grain-morphology, physiology, and biochemistry. In MacGregor, A.W. and Bhatty, R.S. (Eds.). Barley: Chemistry and Technology, p. 33-72. St. Paul, USA: American Association of Cereal Chemists (AACC)

Foschia, M., Peressini, D., Sensidoni, A. and Brennan, C.S. (2013). The effects of dietary fibre addition on the quality of common cereal products. Journal of Cereal Science, 58(2), 216-227. https:// doi.org/10.1016/j.jcs.2013.05.010

Khalil, A.W., Ali, J., Masood, T., Arif, M., Parvez, M. and Hassan, S. (2015). Effect of oat bran on the quality of enriched high fiber biscuits. World Journal of Dairy and Food Sciences, 10(1), 68-73.

Kirssel, L. and Prentice, M. (1979). Protein and fibre enrichment of cookie flour with brewer's spent grains. Cereal Chemistry, 56, 261-265.

Kulp, K. (2000). In Handbook of Cereal Science and Technology, revised and expanded. $2^{\text {nd }}$ ed. Boca Raton, USA: CRC Press. https:// doi.org/10.1201/9781420027228

Lam, T.N.C., Tran, T.T.T., Ton, N.M.N., Le, N.D.D. and Le, V.V.M. (2019). Effects of brewing spent grains ratio on the quality of biscuit with high fiber content. Journal of Agriculture and Rural Development, 19 (22), 72-79

Le Van, V.M., Strehaiano, P., Nguyen, D.L. and Taillandier, P. (2001). Microbial Protease or Yeast Extract-Alternative Additions for Improvement of Fermentation Performance and Quality of Beer Brewed with a High Rice Content. Journal of the American Society of Brewing Chemists, 59(1), 10-16. https://doi.org/10.1094/ASBCJ-59-0010

McCleary, B.V., Draga, A. and Sloane, N. (2013). Dietary fibre analysis in foods. In Delcour, J.A. and Poutanen, K. (Eds.). Fibre-rich and wholegrain foods: improving quality, p. 25-60. Cambridge: Woodhead Publishing Limited. https:// doi.org/10.1533/9780857095787.1.25

Meilgaard, M.C., Carr, B.T. and Civille, G.V. (2006). Sensory Evaluation Techniques. United Kingdom: Taylor and Francis. https://doi.org/10.1201/b16452

Meneses, N.G., Martins, S., Teixeira, J.A. and Mussatto, S.I. (2013). Influence of extraction solvents on the recovery of antioxidant phenolic compounds from brewer's spent grains. Separation and Purification Technology, 108, 152-158. https://doi.org/10.1016/ j.seppur.2013.02.015

Min, D. and Ellefson, W. (2010). Fat Analysis. In Food Analysis, p. 117-132. Boston, USA: Springer. https://doi.org/10.1007/978-1-4419-1478-1_8

Mishra, N. and Chandra, R. (2012). Development of 
functional biscuit from soy flour and rice bran. International Journal of Agricultural Food Science, 2(1), 14-20.

Mosher, M. and Trantham, K. (2016). Brewing Science: A Multidisciplinary Approach. USA: Springer International Publishing. https://doi.org/10.1007/978 -3-319-46394-0

Nandeesh, K., Jyotsna, R. and Venkateswara Rao, G. (2011). Effect of differently treated wheat bran on rheology, microstructure and quality characteristics of soft dough biscuits. Journal of Food Processing Preservation, 35(2), 179-200. https:// doi.org/10.1111/j.1745-4549.2009.00470.x

Noor Aziah, A., Mohamad Noor, A. and Ho, L.-H. (2012). Physicochemical and organoleptic properties of cookies incorporated with legume flour. International Food Research Journal, 19(4), 15391543.

Nwabueze, T. (2006). Water/oil absorption and solubility indices of extruded African breadfruit (Treculia africana) blends. Journal of Food Technology, 4(1), 64-69.

Obafaye, R.O. and Omoba, O.S. (2018). Orange peel flour: A potential source of antioxidant and dietary fiber in pearl-millet biscuit. Journal of Food Biochemistry, 42(4), e12523. https://doi.org/10.1111/ jfbc. 12523

Öztürk, S., Özboy, Ö., Cavidoğlu, İ. and Köksel, H. (2002). Effects of brewer's spent grain on the quality and dietary fibre content of cookies. Journal of the Institute of Brewing, 108(1), 23-27. https:// doi.org/10.1002/j.2050-0416.2002.tb00116.x

Pathare, P.B., Opara, U.L. and Al-Said, F.A.-J. (2013). Colour Measurement and Analysis in Fresh and Processed Foods: A Review. Food and Bioprocess Technology, 6(1), 36-60. https://doi.org/10.1007/ s11947-012-0867-9

Petrović, J.S., Pajin, B.S., Kocić-Tanackov, S.D., Pejin, J.D., Fišteš, A.Z., Bojanić, N.Đ. and Lončarević, I.S. (2017). Quality properties of cookies supplemented with fresh brewer's spent grain. Food and Feed Research, 44(1), 57-63. https://doi.org/10.5937/ FFR1701057P

Quiles, A., Campbell, G.M., Struck, S., Rohm, H. and Hernando, I. (2018). Fiber from fruit pomace: A review of applications in cereal-based products. Food Reviews International, 34(2), 162-181. https:// doi.org/10.1080/87559129.2016.1261299

Slavin, J. (2013). Fiber and Prebiotics: Mechanisms and Health Benefits. Nutrients, 5(4), 1417-1435. https:// doi.org/10.3390/nu5041417

Sudha, M., Vetrimani, R. and Leelavathi, K. (2007).
Influence of fibre from different cereals on the rheological characteristics of wheat flour dough and on biscuit quality. Food Chemistry, 100(4), 13651370. j.foodchem.2005.12.013 https://doi.org/10.1016/ 